\title{
Biological attributes of lemon: A review
}

\author{
Sania Rafique ${ }^{1}$, Syeda Mona Hassan ${ }^{1 *}$, Shahzad Sharif \\ Mughal', Syed Khurram Hassan ${ }^{2}$, Nageena Shabbir', \\ Sumaira Perveiz ${ }^{1}$, Maryam Mushtaq ${ }^{1}$ and Muhammad \\ Farman ${ }^{3}$ \\ 'Department of Chemistry, Lahore Garrison University, Lahore, Punjab, Pakistan \\ ${ }^{2}$ Institute of Quality and Technology Management, University of the Punjab, Lahore, Pakistan \\ ${ }^{3}$ University of Management and technology Lahore, Pakistan
}

Received: 05 May, 2020
Accepted: 21 May, 2020

Published: 22 May, 2020

*Corresponding author: Syeda Mona Hassan, Department of Chemistry, Lahore Garrison University, Lahore, Punjab, Pakistan, E-mail: s.monahasssan@lgu.edu.pk

Keywords: Anti-cancer; Anti-ulcer; Anti-microbial; Antidiabetic; Lemon

https://www.peertechz.com

Check for updates

\begin{abstract}
The citrus fruits are originate to be frequently in cultivation throughout the tropics and are extremely nutritious and medicinal in nature. According to Ayurveda, different parts of Lemon tree possess various medicinal properties. Many properties such as anti-inflammatory, anti-viral, anti-oxidant and anti-diabetic are shown by lemon. In the present review important effects such as anti-fungal, anti-oxidant, anti-inflammatory, anticancer, antibacterial, anti-ulcer and desorption also have been studied In lemon, very important natural compounds containing ascorbic acid, minerals, citric acid, essential oils and flavonoids are present in high quantity ${ }^{9}$ lemon shows anticancer and antibacterial activity due to the presence of alkaloid constituent in different parts of lemon leaves, stem, root and flower. Millennium development goals (MDGs) have one of the fundamental goal which is the quest to combat the incidence of diseases such as kidney stone, respiratory disorder, cancer blood sugar balance and cardiovascular diseases. The potential sources of drugs are secondary metabolites due to their therapeutic importance. These secondary metabolites are rich in medicinal plants.
\end{abstract}

\section{Introduction}

In advanced and undeveloped countries, due to no side effect and natural origin, usually herbal medicines are used. From medicinal plants, many customary medicines are derived which can be used. There are 21,000 plants which are used for medicinal purposes all around the world are listed by World Health Organization (WHO). According to the World Health Organization (WHO), the best sources to acquire the diversity of drugs are medicinal plants. The largest manufacturer of medicinal plants is India which is also called botanical garden of world [1]. In family Rutaceae, the genus Citrus is greatest operational herb in traditional medicines. In tropical and subtropical areas of Asia, the native genus is citrus. The main winter fruits are the citrus fruits which are used up in the diet of Mediterranean. The citrus fruits are originate to be frequently in cultivation throughout the tropics and are extremely nutritious and medicinal in nature. In Mediterranean region, there are eight taxa have been traditionally cultivated belonging to the genus Citrus.

\section{History}

(Rutaceae). For citrus lemon, the most common name is lemon and it is an edible fruit. After orange, lemon is the third most significant specie of citrus fruits which is cultivated more than 4.4 million ton in each year. At present, the biggest producer of lemons in the world is Argentina with 1.2 million tones. In lemon, very important natural compounds containing ascorbic acid, minerals, citric acid, essential oils and flavonoids are present in high quantity [2]. Lemon shows anticancer and antibacterial activity due to the presence of alkaloid constituent in different parts of lemon leaves, stem, root and flower [3]. There are different varieties of lemon include: Avon, Berna, Baboon, Bearss, Cameron [4]. Peels of lemon consist of various phytochemicals, such as glycosides, volatile oils, $\beta$ and $\gamma$-sitosterol. There are various significant activities found in lemon like polyethoxylated, ascorbic acid, flavones, phenolic compounds which are exceptional in other plants.

In 200A.D, lemon plant was first introduced in southern 
Italy and then taken to Iraq and Egypt in 700 A.D. Lemon was distributed in the Mediterranean Region by 1000-1150A.D and then cultivated in China approximately 760-1297 A.D. Lemon was brought into Spanish and then to Island in Hispaniola in 1493. Lemon was launched in California in 1751 -1786 [5].

\section{Graphical distribution}

It is native in north Indian but cultivated in Turkey, Mexico, United States, Argentina, Iran, Brazil, Italy, Spain and People Republic of China. The fruit of lemon can be used for non-culinary and culinary purposes all over the world. Predominantly, lemon is used for its juice from side to side the pulp and taste is as well used mostly in baking and cooking [6].

\section{Toxicological Classification:}

Kingdom: Plantae

Subkingdom: Angiosperms

Phylum: Eudicots

Class: Rosids

Order: Sapindales

Family: Rutaceae

Genus: Citrus

Species: C. Limon

\section{Botanical description}

Citrus trees produce fruits of different shapes and sizes (from round to oblong), these trees are evergreen and full of flavor, fragrance, and juice [7]. The color of leaves of lemon is dark green; these are 6.5 to $10 \mathrm{~mm}$ and are arranged on stem in alternate manners. There are five petals in lemon with white fragrant color. The pulp of lemon is highly acidic and its flower is bisexual and male. 'Pink Lemonade' is lemon cultivar from which the flower of lemon originates. The fruit of this cultivaris striped and leaves are variegated. Commonly lemons are oval in shape with smooth and spongy surface [8]. Lemons are varied in their shapes and sizes, some are like grape fruits and some are little bigger in size. Lemons are mostly greenish yellow in color after gaining its full size it shows bright yellow color instead of greenish yellow. The small seeds are found with-in the fruit called floopies [9] Figures 1-3.

\section{Phytochemicals and nutrition's values}

Phytonutrients shows the biological relationship between plants and human health. Mainly phytonutrients are those bioactive nutrients which are extracted from plants for the benefit of mankind. Citrus fruits are rich in phytoconstituents and lemon is one of them. Citrus fruit is rich of flavonoid glycosides, coumarins and volatile oils [10]. Citrus fruit is rich in flavonoid, glycosides, coumarins, $\beta$ and $\gamma$ sitosterol Citrus fruits constitute only $0.9 \%$ of total daily calories and $1.7 \%$ of daily carbohydrate. Polymethoxylated flavones have much importance and are very rare in other plants. Fiber of citrus

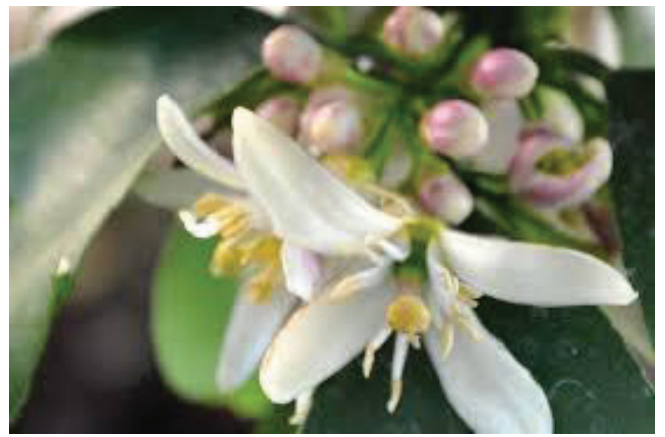

Figure 1: Lemon bud and Flower.

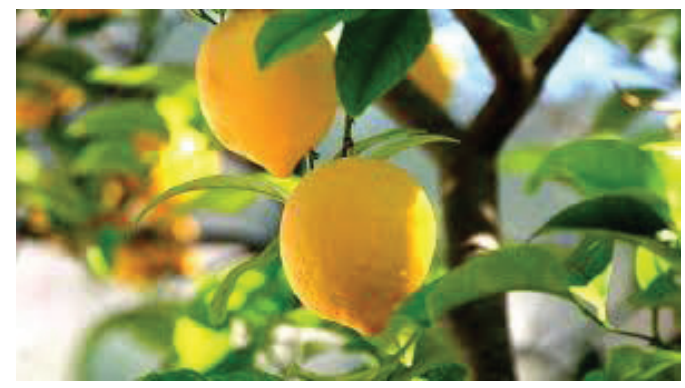

Figure 2: Lemon Fruit.

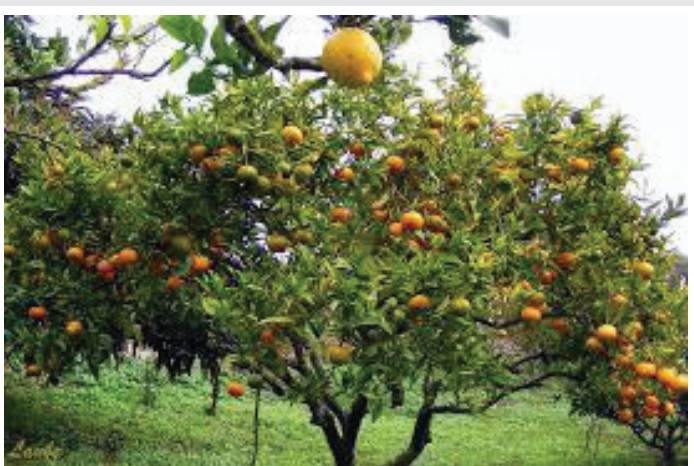

Figure 3: Lemon tree and Fruit.

fruits contains bioactive compound, such as polyphenols, the most important being vitamin $\mathrm{C}$ (or ascorbic acid) and it cure the deficiency of vitamin C.

Citrus limonene has been analyzed for their content of nutrient, carbohydrates, protein, fats, sodium or cholesterol. The $100 \mathrm{~g}$ of lemon without peel having the energy value121 $\mathrm{kJ}$ (29 kcal) carbohydrates $9.32 \mathrm{~g}$, Fat $0.30 \mathrm{~g}$, zinc, $0.06 \mathrm{mg} \mathrm{(1 \% ),}$ calcium $26 \mathrm{mg}(3 \%)$, potassium $138 \mathrm{mg}(3 \%)$, magnesium, 8 $\mathrm{mg}(2 \%)$, iron $-0.60 \mathrm{mg}(5 \%)$,phosphorus $16 \mathrm{mg}(2 \%)$, protein $1.10 \mathrm{~g}$, riboflavin is also known as Vit. B2 $0.020 \mathrm{mg}(1 \%)$, thiamine also known as vitamin B10.040 mg 3\%,pantothenic acid (B5) - $0.190 \mathrm{mg}(4 \%)$, ascorbic acid also called vitamin C $53.0 \mathrm{mg}(88 \%)$

Vitamin B6-0.080 mg (6\%), Niacin (Vit. B3) - $0.100 \mathrm{mg}$ (1\%), folate (Vit. B9), $11 \mu \mathrm{g}$ (3\%) (Hashemipour et al., 2016). A considerable amount of carotenoids and a big quantity of vitamin C (approximately are able of changing to vitamin A), fiber and folate. A large amount of mono-terpene hydrocarbons 
(7095\%) is present in citrus oils along with lesser aggregates of sesquiterpene hydrocarbons and these are responsible for a characteristic flavor [10].

\section{Medicinal uses}

Lemon was cure the plague and a syrup known as acridine citri is prepared from its juice which is used for quenched the thirst of someone and also fought over at the same time. Honey is boiled with lemon and used as digests. It is also used for the removal of pimples and dark spots on face [11].

To kill the intestinal worms, to remove the kidney stone and gravel, lemon juice was used [12]. It is suggested by the various reports that, reduction in oxidative stress, prevention in atherogenic modifications of LDL cholesterol, improve in the blood lipid profile, platelet aggregation and improves HDL-cholesterol concentrations have been done by drinking substantial volumes of a mixture of citrus juices. It is studied that its extract has anti-thyroidal properties, which suggest its potential to ameliorate hyperthyroidism [11].

Due to their similar phytonutrient contents, all citrus fruits contain nutritional and therapeutic properties. The main source of primates' device vitamin $\mathrm{C} 1$ is citrus. Absorption of iron from small intestine in the body is enhanced by ascorbic acid which is compulsory for connective metabolism particularly the scar tissue, teeth and bones. It is essential as an anti-stress and defender against chills damp and cold. It quenches and scavenge the free radical created by ultra violet radiation stabilization, It performances also as antioxidants in the skin [7].

The collagens production is also reliant on vitamin $\mathrm{C}$. Collagens supports in the advancement and renewal of skin and fine wrinkles are improved by it. Total number of protein in the body and its energetic constituent are increased by its extracts which are responsible for the raise of protein serum such as d- limonene. Citrus fruits and their peels are found to help in improving various metabolic and inflammatory disorders attributing to the abundance in its bioactive compounds [13].

\section{Pharmacological activities}

Due to their physiological, medicinal and pharmacological activities, many Citrus species are recognized which includes antioxidant, anti-inflammatory, hypoglycemic, anticancer and antimicrobial activities. Studies have also shown that the main compound of $\mathrm{C}$. limon essential oil D-limonenein concentrations of $0.5 \%$ and $1.0 \%$, administered to mice by inhalation, has a significant calming and anxiolytic effect by activating serotonin and dopamine receptors [14]. In addition, D-limonene has an inhibitory effect on pain receptors, similar to that of indomethacin and hyoscine. The pharmacological potential of C. limon is determined by its rich chemical composition. The most important group of secondary metabolites in the fruit includes flavonoids and also other compounds, such as phenolic acids, coumarins, carboxylic acids, amino acids and vitamins. The main compounds of essential oil are monoterpenoids, especially D-limonene. These valuable chemical components are the reason for the important position of C. limon in the food and cosmetics industries. Another pharmacopoeial raw material obtained from C. limon is the outer part of the mesocarp-the flavedo. A monograph entitled 'Citrus limon flavedo' can be found in older editions of the French Pharmacopoeia, for example, in its 10th edition from 1998. C. limon also has a positive recommendation in the European Commission's Cosmetics Ingredients Database (CosIng Database) as a valuable plant for cosmetics' production [15].

\section{Anticancer}

An irregular growth of cells or tissues of body is called cancer. If abnormal cells divide without control and invade nearby tissues is called malignant tumor and also known as malignancy. If the abnormal cell growth does not invade nearby tissues is called benign tumor or non-cancerous growth. A number of chemo protective activities and chemicals are found in plants in which some of these are taking as clinical experiments.

A novel procedure for cancer therapy is Inhibition of angiogenesis. The selected plants may be carefully used as anti-angiogenic therapy and in cancer controlling [14]. Citrus limonene contain vitamin $\mathrm{C}$, folate, dietary fibre and other bioactive components, such as carotenoids and flavonoids, which are suggested to be responsible for the prevention of cancer and degenerative disease. Citrus liminoids shows anticancer property in aqueous extract of fruit, containing those compounds which shield the cells from damage which is the cause of cancer [16].

\section{Antioxidant activity}

The important sources of antioxidants are citrus juices and fruits and these antioxidants are ascorbic acid, flavonoids and phenolic compounds [17]. The source of glycosides and phenolic compounds are citrus peels. The bioactive compounds are phenolic acids which are responsible for the antioxidant and many other biological activities [18]. The highest antioxidant activity can be found in citrus fruits. Ascorbic acid (vitamin C) interpretations for a great proportion in some fruits can act as antioxidant. Moreover, other phytoconstituents like carotenoids, flavonoids, glutathione, and various enzyme systems may also contribute to the antioxidant activity [19].

\section{Anti-ulcer activity}

The pathophysiology of peptic ulcer dieses involves an imbalance between offensive (acid, pepsin, and $\mathrm{H}$. pylori) as well as suspicious aspects [14]. Indian Medicinal plants and their derivatives have been a valuable source of therapeutic agents to treat various disorders including Antiulcer diseases. Fruit aqueous excerpt also shows the antiulcer activity against gastric ulcer [20].

\section{Anti-diabetic activity}

A metabolic disorder is called Diabetes. A system, through which our body utilizes the digested food energy and growth, is known as metabolism. The eaten food is converted into a

Citation: Rafique S, Hassan SM, Mughal SS, Hassan SK, Shabbir N (2020) Biological attributes of lemon: A review. J Addict Med Ther Sci 6(1): 030-034. 
form of blood sugar and the basic component of blood sugar is called glucose. The main source of fuel for our body is glucose. In absence of insulin, glucose cannot enter our cells. A class of organic substance known as polyphenols which is present in lemon and a high amount in lemon peel [13]. It is investigated that polyphenols considerably inhibited the fat accumulation, high blood glucose levels and insulin resistance, development of hyper lipidemia, weight gain which are different aspects of obesity. A range of essential oils is present in citrus peel. The pathogenic bacteria are killed or their growth is inhibited by suing these essential oils. The lowering of diabetes and antiper oxidative effects are possessed by citrus peel due to the high content of total polyphenols [14].

\section{Antimicrobial activity}

The antibacterial activity of the organic acid-rich extract of fresh red chicory was verified against predontopathic bacteria like actionmycies and streptococcus mutant. Oxalic acid and succinic acid were recognized from active extract .entire organic acid with variant level of efficiency were present to reducing biofilm generation and adhesion of bacteria to the cell. The antibacterial activity was analyzed by well diffusion method. $25 \mathrm{~mL}$ of Muller Hinton agar was prepared according to the standard procedure and poured into the plates and then it is allowed to get hard. The inoculums suspension are taken as standard which streaked over the surface of the media by using sterile cotton pad to make sure the confluent development of the organism and 5 minutes are allowed to dry the plates. The different concentrations (50, 75 and $100 \mu \mathrm{g} / \mathrm{mL}$ ) of the extract were poured into the wells after drying. A standard $(1 \mu \mathrm{g} / \mathrm{mL})$ which is used called Tetracycline. Finally, the bacteria are incubated at $37^{\circ} \mathrm{C}$ for 24 hours in the inoculated plates [21-24]

\section{Conclusion}

One of the most important sources of medicines are plants. It is well documented from ancient times till date all over the world, medicinal plants are stimulating the ability of human health to handle with the unpleasant and difficult circumstances. A millennium development goal (MDGs) has one of the fundamental goal which is the quest to combat the incidence of diseases such as kidney stone, respiratory disorder, cancer blood sugar balance and cardiovascular diseases. The potential sources of drugs are secondary metabolites due to their therapeutic importance. These secondary metabolites are rich in medicinal plants. As therapeutic agents, the interest in the use of plant extracts is increasing. A "citrus fruit" lemon belongs to family Rutaceae which is used in pharmacological potential as solution. One of the most popular fruit is lemon in all over the world. From the literature investigation, it is stated that a potential source of anti-diabetic, anticancer, antimicrobial and anti-inflammatory activity is lemon.

\section{References}

1. Vijayalakshmi K, Selvaraj $\mathrm{Cl}$ (2018) Medicinal Plants and their PhytoConstituents with Potential Antidiabetic Activity-A Review. Res J Biotechnol 13. Link: https://bit.ly/3cYYpEY

2. Makni M, Jemai R, Kriaa W, Chtourou Y, Fetoui $H$ (2018) Citrus limon from
Tunisia: Phytochemical and physicochemical properties and biological activities. Biomed Res Int Link: https://bit.ly/2zY3dvF

3. Dhanavade MJ, Jalkute CB, Ghosh JS, Sonawane KD (2011) Study antimicrobial activity of lemon (Citrus lemon L.) peel extract. Br J Pharmacol Toxicol 2: 119 122. Link: https://bit.ly/2ZoDkzX

4. Mshelia BM, Adeshina GO, Onaolapo JA (2018) The antibacterial activity of honey and lemon juice against Streptococcus pneumoniae and Streptococcus pyogenes isolates from respiratory tract infections. Acta Sci Microbiol 1. Link: https://bit.ly/3eeeRBz

5. Ali J, Das B, Saikia T (2017) Antimicrobial activity of lemon peel (Citrus limon) extract. International Journal of Current Pharmaceutical Research 9: 79-81. Link: https://bit.ly/2TxLx10

6. Mohanapriya M, Ramaswamy L, Rajendran R (2013) Health and medicinal properties of lemon (Citrus limonum). International Journal of Ayurvedic and Herbal Medicine 3: 1095-1100. Link:

7. Okwu DE (2008) Citrus fruits: A rich source of phytochemicals and their roles in human health. Int J Chem Sci 6: 451-471. Link: https://bit.ly/2XicsPu

8. Zhao J (2007) Nutraceuticals, nutritional therapy, phytonutrients, and phytotherapy for improvement of human health: a perspective on plant biotechnology application. Recent Pat Biotechnol 1: 75-97. Link: https://bit.ly/2WXz5K9

9. Gamarra F, Sakanaka L, Tambourgi E, Cabral F (2006) Influence on the quality of essential lemon (Citrus aurantifolia) oil by distillation process. Brazilian Journal of Chemical Engineering 23: 147-151. Link: https://bit.ly/3eeeneJ

10. Ahmad MM, Iqbal Z, Anjum F, Sultan J (2006) Genetic variability to essentia oil composition in four citrus fruit species. Pakistan Journal of Botany 38: 319. Link: https://bit.ly/36obaXd

11. Uduak OA, Ani EJ, Etoh ECl, Macstephen AO (2014) Comparative effect of Citrus sinensis and carbimazole on serum T4, T3 and TSH levels. Niger Med J 55: 230-234. Link: https://bit.ly/36kWWX0

12. Arias BA, Ramón-Laca $L$ (2005) Pharmacological properties of citrus and their ancient and medieval uses in the Mediterranean region. J Ethnopharmacol 97 89-95. Link: https://bit.ly/2zjt5IC

13. Sridharan B, Michael ST, Arya R, Mohana Roopan S, Ganesh RN, et al. (2016) Beneficial effect of Citrus limon peel aqueous methanol extract on experimentally induced urolithic rats. Pharm Biol 54: 759-769. Link: https://bit.ly/3e800z7

14. Umashanker M, Shruti S (2011) Traditional Indian herbal medicine used as antipyretic, antiulcer, anti-diabetic and anticancer: A review. Int J Res Pharm Chem 1: 1152-1159. Link: https://bit.ly/2zawq6J

15. Klimek-Szczykutowicz M, Szopa A, Ekiert H (2020) Citrus limon (Lemon) Phenomenon-A Review of the Chemistry, Pharmacological Properties, Applications in the Modern Pharmaceutical, Food, and Cosmetics Industries, and Biotechnological Studies. Plants 9: 119. Link: https://bit.ly/2LPrhn5

16. Tripoli E, La Guardia M, Giammanco S, Di Majo D, Giammanco M (2007) Citrus flavonoids: Molecular structure, biological activity and nutritional properties: A review. Food chemistry 104: 466-479. Link: https://bit.ly/2TudOFC

17. Moosavy M, Hassanzadeh $\mathrm{P}$, Mohammadzadeh $\mathrm{E}$, Mahmoudi R, Khatibi S, et al. (2017) Antioxidant and antimicrobial activities of essential oil of Lemon (Citrus limon) peel in vitro and in a food model. Journal of food quality and hazards control 4: 42-48. Link: https://bit.ly/2XyUOST

18. ChunYan H, Hong P, ZhenYu Z, Jing S (2010) Evaluation of antioxidant and antitumour activities of lemon essential oil. J Med Plants Res 4: 1910-1915. Link: https://bit.ly/3gfmeKT

19. Oikeh El, Omoregie ES, Oviasogie FE, Oriakhi K (2016) Phytochemical, antimicrobial, and antioxidant activities of different citrus juice concentrates. Food Sci Nutr 4: 103-109. Link: https://bit.ly/2zWvu5Y

Citation: Rafique S, Hassan SM, Mughal SS, Hassan SK, Shabbir N (2020) Biological attributes of lemon: A review. J Addict Med Ther Sci 6(1): 030-034. 
20. Nagaraju B, Anand S, Ahmed N, Chandra JNS, Ahmed F, et al. (2012) Antiulcer activity of aqueous extract of Citrus medica Linn. fruit against ethanol-induced ulcer in rats. Adv Biol Res 6: 24-29. Link: https://bit.ly/3bRzykX

21. John S, Monica SJ, Priyadarshini S, Sivaraj C, Arumugam P (2017) Antioxidant and Antimicrobial Efficacy of Lemon (Citrus limonum L.) Peel. Int J Pharm Sci Rev Res 46: 115-118. Link: https://bit.ly/3gdBNmd

22. ChunYan H, Hong P, ZhenYu Z, Jing S (2010) Evaluation of antioxidant and antitumour activities of lemon essential oil. J Med Plants Res 4: 1910-1915. Link: https://bit.ly/3gfmeKT
23. Hajimahmoodi M, Aliabadipoor M, Moghaddam G, Sadeghi N, Oveisi MR et al. (2012) Evaluation of in vitro antioxidant activities of lemon juice for safety assessment. Am J Food Technol 7: 708-714. Link: https://bit.ly/2XiVTTj

24. Hashemipour M, Kargar M, Ghannadi A, Kelishadi R (2016) The effect of Citrus Aurantifolia (Lemon) peels on cardiometabolic risk factors and markers of endothelial function in adolescents with excess weight: A triplemasked randomized controlled trial. Med J Islam Repub Iran 30: 429. Link: https://bit.ly/3cUrqBJ

\section{Discover a bigger Impact and Visibility of your article publication with}

\section{Peertechz Publications}

\section{Highlights}

* Signatory publisher of ORCID

* Signatory Publisher of DORA (San Francisco Declaration on Research Assessment)

* Articles archived in worlds' renowned service providers such as Portico, CNKI, AGRIS, TDNet, Base (Bielefeld University Library), CrossRef, Scilit, J-Gate etc.

* Journals indexed in ICMJE, SHERPA/ROMEO, Google Scholar etc.

* OAI-PMH (Open Archives Initiative Protocol for Metadata Harvesting)

* Dedicated Editorial Board for every journal

* Accurate and rapid peer-review process

* Increased citations of published articles through promotions

* Reduced timeline for article publication

Submit your articles and experience a new surge in publication services (https://www.peertechz.com/submission).

Peertechz journals wishes everlasting success in your every endeavours.

Copyright: @ 2020 Rafique S, et al. This is an open-access article distributed under the terms of the Creative Commons Attribution License, which permits unrestricted use distribution, and reproduction in any medium, provided the original author and source are credited. 